\title{
TWINKLE, TWINKLE MEGA STAR: MEGACITY KARACHI, FUTURE CAPITAL OR NOT
}

\author{
Dr. Mustafa Hyder (Corresponding author) \\ Assistant Professor; \\ Department of Public Administration, \\ University of Karachi, Pakistan \\ Tel: +923002182405 E-mail: mustafahyder@uok.edu.pk \\ Salman Ahmed Khatani \\ Lecturer; \\ Department of Business Administration; \\ Iqra University, Karachi, Pakistan \\ Tel: +923222956050 E-mail: salmankhatani@hotmail.com
}

\begin{abstract}
In history cities have held prominent places either because of their political or commercial impact or their social and cultural contributions, same is the case of Karachi that also claims to have deep rooted heritage and an intriguing civilization to its name. This city was founded by a Hindu tradesman, was named after a local woman 'Mai Kolachi'. The contemporary Karachi's journey can be written down in four clear stages. First stage is of the colonial Karachi, secondly Karachi as the capital of a newly born country, third comes a disarrayed Karachi in search of its identity and finally the most recent stage of it as the 7th largest megacity of the world. The objective of this paper is to view Karachi in light of these stages and try to understand why it was chosen as the capital of Pakistan and what circumstances occurred to shift capital to Islamabad. Does Karachi still have the potential to become the capital of Pakistan again? This issue weighs heavy in the politics and some political parties have already used it for their election campaigns. Our leaders claim that they will make Karachi the future capital of Pakistan; is this a feasible or a doable claim; this paper aims to answer this question.
\end{abstract}

Keywords: Megacity Karachi, Contemporary Karachi, Karachi Future Capital

DOI: $10.7176 / J E S D / 10-3-12$

\section{INTRODUCTION:}

Throughout history cities with major political or commercial impact or social and cultural contribution have held special places. Karachi also has some socio-cultural attributes. Karachi was a fishermen's town which was named after a women Mai Kolachi (Askari, 2015) and was developed by a Hindu merchant Bhojomal in 1729 (Mubarak, 2011) as a port. Though Karachi does not share very deep heritage and archeological depth like other capitals of this region but still it has strong and rich stories of politics which can be clearly divided into four historical stages.

I. Colonial Karachi under British Empire

II. Karachi the capital of a newly born Pakistan

III. Karachi in search of its identity

IV. Karachi the $7^{\text {th }}$ largest megacity of the World

From a small fisherman town to a glorified financial hub, over the time it has undergone many faceted evolutions each highlighting Karachi's geographical, social and economic importance.

\section{COLONIAL KARACHI UNDER BRITISH EMPIRE}

The Britishers took over Karachi in 1839 and they glorified this city with their keen interest. T.G. Carless wrote about Karachi when it was not occupied, "At present Kurachee has a population of 14,000 souls, half of which are Hindoos, and the rest Baloochees, Jokeeaahe, Mowannas, and Jutts."(Carless, 1939) Once Karachi became a prominent seaport of sub-continent and people from all over India were attracted to it. Karachi became a homogenized city of approximately $3,86,655$ people before partition.

According to Dr. Mubarak Ali, "Jamshid Nasarvanji Mehta served as the president of the municipality from 1921 to 1933 . During this period sanitation was improved, supply of water was regulated, roads were repaired, gardens 
were laid out, maternity homes were built, new housing schemes were started to solve the problems of housing, and a majestic municipal building was constructed. As a result of his efforts the city got a new look. It became a model of cleanliness." (Mubarak, 2011) This was the golden era of 'colonial Karachi'.

\section{KARACHI THE CAPITAL OF A NEWLY BORN PAKISTAN}

Upon independence of Pakistan, Karachi was selected as its capital by M. A. Jinnah the founding father of Pakistan in 1947 (Prentice, 1966). However Karachi had earned this status of capital overnight and there was no proper infrastructure for government offices or officials. Above this the post partition migration was bringing hordes of people from all over India to Pakistan and especially to Karachi, resulting in a massive increase in the city's population. These refugees belonging to various parts of India also brought their indigenous cultures, ideologies as well as prejudices with them. The local natives were pushed back into the nooks of the city and the Mohajirs (immigrants) started settling in the heart of Karachi city. Urdu became the language of daily use and these Mohajirs created a good intellectual environment in this city (Hasan, 1995). Due to all these changes the dynamics of the city was turning out well until Ayub Khan took over government with his military coup and disturbed all the fibers of this peaceful fabric of the city.

City which is the capital of any state or any administrative center is supposed to be the focal point of the power, culture and main residing points of the premiers but at the time of Ayub Khan this was not the case with Karachi. Once Ayub Khan took over all the power houses were supposed to be near army's GHQ and that was why he wanted the capital to be shifted somewhere near it (Tayyeb, 1996). So in 1958 a new capital near Rawalpindi was announced by Ayub Khan and in 1959, the national assembly was also shifted to Rawalpindi.

It is of course arguable that this might not have been the only reason for relocation of the capital and over time many debates occurred favoring either sides of this decision. Those who disagreed with the decision for new capital argued that Karachi, as the birthplace of the father of the nation accrued a special symbolic representation. Also its safe and strategically important location along with it being a hub for all types of demographic groups made it an attractive option for a capital. Besides that Karachi had never had the status of Capital under any colonial or sovereign regime before. On the other hand were those like Doxiadis the chief planner of Islamabad, who highly favored this move. They opined that even though initially Karachi was a suitable choice for the country's capital due to its adequate infrastructure and ready resources but with time Karachi had become over crowded, congested and polluted, and could not continue being the capital (Doxiadis, 1965).

Another reason for which, Karachi was not deemed fit for being a capital was that its people and especially the educated youth had become more politically active and were giving a tough time to the dictator of the regime (Mubarak, 2011). Also the people favoring Islamabad used this very argument of diversity to point out that Karachi had no representation of the national identity, loyalty and stability required for smooth operations of Government, although this argument is no more valid as Karachi now has become mini Pakistan and residence of the people belonging to every part of the country.

\section{KARACHI IN SEARCH OF ITS IDENTITY}

Karachi entered its third phase after 1970 in which time the city and its residents were in a turmoil regarding their true identity and status. One unit system was dismissed and Karachi was chosen as the capital of Sind province. Upon this Sindhi speaking public from all over Sind started trickling into Karachi and began taking over all the key government positions on the basis of 'quota' system (Kennedy, 1991) or for being the largest ethnical group of the province. Added to this, Bhutto who was an indigenous Sindhi himself became the First Civilian Field Marshall of West Pakistan after the fall of Dhaka. Such remained the circumstances of Karachi till 1999 in which time only a few privileges were sanctioned to the former majority of Urdu speaking public, which once enjoyed the monopoly of power in earlier decades.

\section{KARACHI THE 7TH LARGEST MEGACITY OF THE WORLD}

A drastic movement that changed the fate of this city occurred between 2002 and 2008 when Karachi went under the power and political ownership of the native people owing to President Musharraf's initiation of local Government policy (Gazdar, 2011). Over the years exponential increase in Karachi's population was being observed and in 2015 Karachi was ranked as the $7^{\text {th }}$ largest megacity in the world with an estimated population of over 22 million, with its youth (median age 21), alone, exceeding 7 million (Salman,2016).

\section{CAN KARACHI BECOME THE CAPITAL OF PAKISTAN AGAIN?}

When some political parties like MQM and PTI demand Karachi to be renamed as the new capital of Pakistan as opposed to Islamabad it is obviously a game of political point scoring and a new meme for election campaigns. But whether this option really is feasible or not, can be analyzed in light of the following aspects. 


\section{Geographical Aspect:}

Asia is most of the World and Pakistan is located in the heart of Asia and Sindh is the gateway of Pakistan and Karachi is the blood supply of Pakistan. The city is one of the most important and geographically located industrial hub with five industrial zones and two ports on the Arabian Sea. Total area approx. 3,527 Km. Sq. with 22million population makes the MegaCity busy for trade and commercial activities.

\section{Infrastructure Aspect:}

The worth of any capital city is determined by the size and organization (Doxiadis, 1965). A capital city should have enough space for government offices, buildings and staff residence. However in case of Karachi there is no space for massive construction projects what with it being an over-congested, over polluted city, although vertical growth is there in the city but improper planning and infrastructure is there.

\section{Economic Aspect:}

Being the port city and the gateway to Pakistan trade, Karachi proves to be an economic engine, a commercial and financial capital of Pakistan with entire nation as its stakeholder. Karachi generates around $70 \%$ of the entire country revenue but get very little in NFC awards due to incorrect population statistics as a result the city administration don't have enough economic resources and development funds, which the city certainly deserve. If Karachi gets what it deserve no one can stop it to become one of the leading city in the entire world.

\section{Social Aspects:}

A capital of a country is its center of power and policy making therefore it should not be associated with any one ethnic or political group. The inhabitants of a capital city should present a balanced ratio of cultural and sub cultural mixes so as to represent the whole country. All megacities have a special force of attraction for employment, quality of life and other civic facilities, people from entire country moves in such cities and Karachi is one of those cities who have a strong centripetal force. From this point of view, Karachi suites to be a financial capital as Karachiites are from entire Pakistan that's why people claim the city as mini Pakistan. All social, cultural and ethnical representation is here.

\section{Cultural Aspects:}

Change is inevitable and Karachi of today is much different from what it was originally, it is now a megacity where people from all other provinces and especially from rural Sind migrated (Haq, 1995) to change their lives for a better future. This transition process has definitely caused disturbances in the previous key attributes of Karachi like its homogenized culture, peace and prosperity. Now not many native Karachiites are left in the city that are haunted by its part glories since mostly it is inhabited by fairly new settlers who have no knowledge of its previous magnificence.

\section{Technological Aspects:}

From technological point of view, though Karachi has enough resources in place and skilled people too but the way this city is expanding without any planning or urban strategy is resulting in chaos. Areas like education, health care, transportation; water supply, sewerage, and sanitation, employment, communications and population growth are all outdated.

\section{Ekistics:}

Any human settlement consists of five elements: nature, man, society, networks (roads, power, etc.), houses and buildings (Doxiadis, 1965). However, Karachi does not have enough means to fulfill all these basic necessities of its residents adequately because its population is increasing tremendously and this population shift is fostering rapid urbanization for which this city is not yet ready or equipped (Zaidi, 1997).

\section{CENTRES OF GRAVITY}

Before a city can be considered for the position of a capital its location must be closely scrutinized. Whether it falls in the center of the country, can it make a good hub of activity, whether it is safe and secure from the probable enemy attacks etc. On this account Islamabad is a competent and very apt choice especially due to its location on the Grand Trunk Road where most of the previous successful capitals of the region were situated like Tehran, Kabul, Peshawar, Lahore, Delhi and even Taxila in era of Alexander. Geographic and historical forces placed the capitals on the same line (Doxiadis, 1965).

\section{CONCLUSION}

As can be judged by these few key factors above that even though "Karachi as new Capital" makes for good election campaigns and slogans but in practicality this is not a viable option. Many more factors have to be 
considered rather than mere sentiments when choosing a capital of a country. So even though Karachi is going to be a future universal city with growing infrastructure, horizontal and vertical growths, becoming trade and financial hub, shall always remain important due to its sea port and growing industrialization but it is unrealistic that it shall ever become the capital of Pakistan again.

\section{References}

Arif Hasan,(1995), “ Karachi city, in Aaj, Autumn, p. 390-91

Askari, Sabiah (2015). Studies on Karachi: Papers Presented at the Karachi Conference 2013. Cambridge Scholars Publishing. ISBN 978-1443877442

Gazdar, H. (2011). Karachi Battles. Economic and Political Weekly, 19-21.

Haq, F. (1995). Rise of the MQM in Pakistan: Politics of ethnic mobilization. Asian Survey, 35(11), 990-1004.

Kennedy, C. H. (1991). The politics of ethnicity in Sindh. Asian survey, 31(10), 938-955.

Malik, I. (1998). What Is Wrong in Karachi? Economic and Political Weekly, 33(33/34), 2219-2221. Retrieved from http://www.jstor.org/stable/4407098

Mubarak Ali, (2011) "Pakistan In Search of Identity" Published in India 2011, ISBN 978-93-5002-099-9, p. $131 / 152$

Prentice, Anne.(1996) "Islamabad: A New Capital City." Geography 51.1 (1966): 58-61.

Tayyeb, A., Pakistan: A Political Geography (London and elsewhere, 1966), p. 178.

T.G. Carless, 1993 'Memoirs on the Bay, Harbour, and Trade, of Kurachee', in Memoirs of Sindh, Hughes Thomas, Vol. I, Delhi, p. 196

Zaidi, S. A. (1997). Politics, institutions, poverty: the case of Karachi. Economic and Political Weekly, 3282-3293.

Doxiadis, C. A. (1965). Islamabad, the creation of a new capital. Town Planning Review, 36(1), 1. 